\title{
Biochar Improves Plant Growth and Reduces Nutrient Leaching in Red Clay Loam and Sandy Loam
}

Kalpana Pudasaini, Nanjappa Ashwath, Kerry Walsh and Thakur Bhattarai
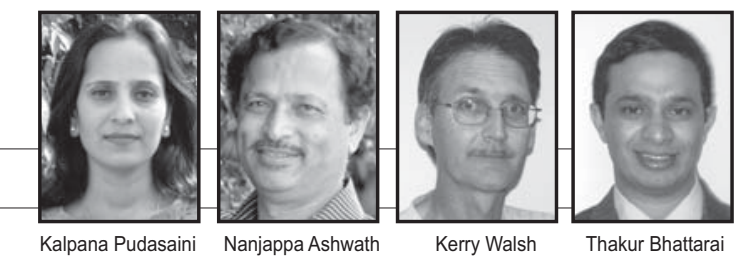

\begin{abstract}
A factorial pot experiment was conducted using two types of soils (sandy loam and red clay loam) that are commonly used for commercial vegetable production in Bundaberg, region of Central Queensland Australia. The soils were amended with $0,25,50$ and $75 \mathrm{t} / \mathrm{ha}$ of green waste biochar and minimum doses of $\mathrm{N}, \mathrm{P}$ and $\mathrm{K}(30 \mathrm{~kg} / \mathrm{ha}, 30 \mathrm{~kg} / \mathrm{ha}$ and $40 \mathrm{~kg} /$ ha respectively). After two weeks of plant establishment, the pots were leached with 1.5 litres of deionised water at week intervals, and cation concentrations of the leachate were determined. In $25 \mathrm{t} / \mathrm{ha}$ biochar treatment, there was a significant $(\mathrm{P}<0.05)$ reduction in $\mathrm{K}$ and $\mathrm{Ca}$ leaching by $40 \%$ and $26 \%$ respectively from sandy loam, and of $\mathrm{Ca}$ by $23 \%$ from the red clay loam. Soil water holding capacity and soil organic carbon were also increased in both biochar treated soils. After 12 weeks of growth, shoot weight was significantly $(P<0.05)$ higher in $25 \mathrm{t} /$ ha biochar-treated sandy loam and red clay loam (32\% and 31\% respectively). These results clearly demonstrated that a higher yield of capsicum can be achieved from green waste biochar application in sandy loam and red clay loam at $25 \mathrm{t} /$ ha biochar.
\end{abstract}

Key words: Green waste biochar, cation leaching, soil cation exchange capacity, carbon sequestration, Australia

\section{Introduction}

Tutrient leaching has a great impact on the 1 environment as well as on nutrient cycling in agriculture (Brady and Weil 2008). Leaching usually occurs due to high rainfall and poor soil properties. Nutrient deficiency is often seen in tropical agricultural soils due to low nutrient retention capacity of the soil and rapid decomposition of the organic residues (Juo and Manu 1996). Nutrient leaching can range as high as to $80 \%$ of nitrogen $(\mathrm{N})$ (Lehmann, Lilienfein et al 2004), $172 \%$ for calcium (Ca) (Omoti, Ataga and Isenmila 1983) and $136 \%$ for applied magnesium $(\mathrm{Mg}$ ) (Cahn, Bouldin et al 1993). Research shows that application of biochar to soil may improve cation exchange capacity (CEC) of the soils, which in turn contributing to a reduction in nutrient leaching (Lehmann, da Silva et al 2003).

Biochar refers to black carbon, formed by heating biomass in an oxygen limited environment, the process commonly known as pyrolysis (Woolf 2008). During pyrolysis, labile biomass carbon changes into stable black carbon which may remain in the soil for thousands of years. Thus, biochar may be an appropriate tool for sequestering atmospheric carbon dioxide in the soil and reducing global warming. In addition, biochar may adsorb soluble nutrients such as ammonium (Lehmann, da Silva et al 2002), nitrate (Mizuta, Matsumoto et al 2004), phosphate (Beaton, Peterson and Baur 1960) and other ionic solutes (Radovic, Moreno-Castilla and Rivera-Utrilla 2001). It has also been reported that surface oxidation and CEC of biochar (Liang, Lehmann et al 2006) can increase over time (Cheng, Lehmann and Englehard 2008), leading to greater nutrient retention. Biochar may also help to retain water in its pores by capillary forces leading to an increase in water holding capacity (WHC) and a decrease in nutrient leaching.

Results of a greenhouse pot experiment indicate that the addition of hard wood biochar to a tropical oxisol led to $60 \%$ reduction in leaching of applied ammonium $\left(\mathrm{NH}_{4}\right)$ over 40 days of cropping with rice (Oriza sativa), as compared to the treatment not receiving biochar (Lehmann, da Silva et al 2003). Leaching of $\mathrm{Ca}$ and $\mathrm{Mg}$ was also reduced in this trial. Major (2009) also found a reduction in leaching of Ca by $23 \%, \mathrm{Mg}$ by $28 \%$ and potassium (K) by $36 \%$ in a $20 \mathrm{t} / \mathrm{ha}$ biochar applied poor acidic soil. The present study was conducted to examine the effect of green waste biochar on soil CEC, soil WHC, cation leaching and plant growth for two soils of horticulture importance in Central Queensland. It was anticipated that biochar addition would result in a greater reduction in leachate from the sandy loam than the red clay loam.

\section{Materials and Methods}

Sandy loam and red clay loam soils that have been widely used for horticultural crop production were collected from a farm near Bundaberg, Central Queensland, Australia. Top soil (o to $0.2 \mathrm{~m}$ depth) was collected, and air dried. The soil was sieved sequentially through a 6 and then a $2 \mathrm{~mm}$ sieve. The $<2 \mathrm{~mm}$ fraction was used in the pot experiment.

Green waste biochar produced by Pacific Pyrolysis, Australia was used in the experiment. This biochar was produced by slow heating of the green waste to a temperature of $550^{\circ} \mathrm{C}$ using a slow pyrolysis system. The green waste was a whole tree residue chipped and passed through a $15 \mathrm{~mm}$ screen. The biochar was alkaline in nature. It had high total carbon but low in total nitrogen and mineral nitrogen (Table 1). The biochar samples were ground and sieved through a $2 \mathrm{~mm}$ sieve. The $<2 \mathrm{~mm}$ fraction was used in the experiment, with capsicum as a test plant. Capsicum was chosen, as this crop grown in this region using high doses of fertilizers (up to $1000 \mathrm{~kg}$ of $\mathrm{N}$, $\mathrm{P}$ and $\mathrm{K}$ per year).

\section{Pot Experiment}

The three months pot experiment was conducted in a glasshouse at CQ University Rockhampton, Australia. A randomised complete block design was used with 8 treatments and three replications. The treatments were: soil types (red clay loam and sandy loam), biochar (o, 25, 50 and $75 \mathrm{t} / \mathrm{ha})$ or $(20 \%, 40 \%$ and $60 \%)$ and fertilizer $(\mathrm{N}-$ $30, \mathrm{P}-30$ and $\mathrm{K}-40 \mathrm{~kg} / \mathrm{ha}$ ). Biochar was mixed thoroughly with eight kilograms air dry soil and filled the plastic pots. Deionised water was added to all pots to bring the soil moisture content up to field capacity. Three weeks old capsicum seedlings (Warlock) were planted in each pot. 
After two weeks, pots were irrigated with excess water to allow collection of leachate. The leachate was filtered and stored in a refrigerator at $4^{\circ} \mathrm{C}$ prior to nutrient analysis. Each pot was provided with 1.5 litres of water above field capacity. Cation concentrations ( $\mathrm{Ca}, \mathrm{Mg}, \mathrm{K}$ and $\mathrm{Na}$ ) of the leachate sample were analysed using an Atomic Absorption Spectrometer (AAS). The leachate collection continued at weekly intervals for 12 weeks. After 12 weeks of growth in the pots, the capsicum plants were harvested. The leaves, stems and fruits from the harvested plants were separated and oven dried at $70^{\circ} \mathrm{C}$ for 72 hours to determine plant dry matter.

\section{Soil Analysis}

The soil samples were collected from selected treatment combinations: red clay loam with fertilizer, red clay loam with fertilizer and biochar (25 t/ha), sandy loam with fertilizer, and sandy loam with fertilizer and biochar (25 $\mathrm{t} / \mathrm{ha}$ ). The soil samples were air dried, crushed and passed through a $2 \mathrm{~mm}$ sieve and sent to CSBP laboratory, Perth, Western Australia for chemicals analysis. Soil and biochar samples were analysed before conducting experiments (Table 1). Soil and biochar CEC were determined by using Ammonium acetate method (Chapman 1965). Soil organic carbon was determined by Walkley Black method (Walkley 1947). Soil WHC of all treatment combinations was also measured.

\begin{tabular}{|c|c|c|c|}
\hline Soil Properties & Biochar & Sandy Loam & Red Clay Loam \\
\hline $\mathrm{NH}_{4}-\mathrm{N}(\mathrm{mg} / \mathrm{kg})$ & $<1$ & $<1$ & $<1$ \\
\hline $\mathrm{NO}_{3}-\mathrm{N}(\mathrm{mg} / \mathrm{Kg})$ & $<1$ & 6 & 4 \\
\hline Colwell Phosphorous (mg/kg) & 79 & 188 & 272 \\
\hline Colwell K (mg/kg) & 23 & 32 & 225 \\
\hline Sulphur (mg/kg) & $<.5$ & 57.1 & 5.66 \\
\hline Organic carbon (\%) & 0.06 & 0.65 & 0.89 \\
\hline Conductivity (dS/m) & 0.29 & 0.118 & 0.063 \\
\hline $\mathrm{pH}\left(\mathrm{H}_{2} \mathrm{O}\right) \mathrm{Ph}$ & 7.2 & 6.7 & 6.7 \\
\hline $\mathrm{pH}\left(\mathrm{CaCl}_{2}\right) \mathrm{pH}$ & 7.4 & 7.4 & 7.2 \\
\hline DTPA Copper (mg/kg) & 1.1 & 2.38 & 14.91 \\
\hline DTPA Iron $(\mathrm{mg} / \mathrm{kg})$ & 23.14 & 12.16 & 16.42 \\
\hline DTPA Manganese $(\mathrm{mg} / \mathrm{kg})$ & 3.05 & 1.01 & 9.88 \\
\hline DTPA Zinc $(\mathrm{mg} / \mathrm{kg})$ & 2.67 & 2.66 & 12.59 \\
\hline Exc. Aluminium (meq/100 g) & $<.001$ & $<.001$ & $<.001$ \\
\hline Exc.Ca (meq/100 g) & 1.77 & 4.73 & 6.8 \\
\hline Exc. Mg (meq/100 g) & 0.7 & 0.17 & 1.75 \\
\hline Exc. K (meq/100 g) & $<.01$ & 0.05 & 0.56 \\
\hline Exc. $\mathrm{Na}(\mathrm{meq} / 100 \mathrm{~g})$ & 1.04 & 0.02 & 0.08 \\
\hline Boron $\mathrm{Hot} \mathrm{CaCl}_{2}(\mathrm{mg} / \mathrm{kg})$ & 0.1 & 0.2 & 1.2 \\
\hline Chloride (mg/kg) & $<.01$ & 1.1 & 0.6 \\
\hline Total carbon \% & 62.9 & 0.64 & 0.75 \\
\hline
\end{tabular}

Table 1. Soil and Biochar Properties.

\section{Statistical Analysis}

All data were analysed by one-way analysis of variance (ANOVA) using GenStat (V13.1). The treatment means were compared using least significant differences for the main effects of biochar.

\section{Results \\ Cation Leaching}

The $\mathrm{K}$ leaching was significantly $(P<0.05)$ reduced by $40 \%$ in the biochar amended sandy loam compared to control (Figure 1). However, there was no significant change in response to biochar addition in red clay loam (Figure 1).

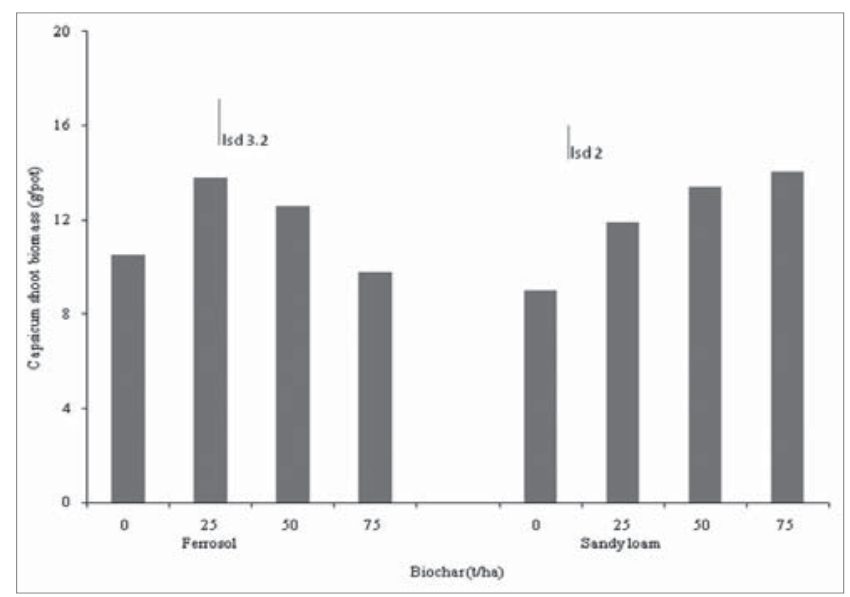

Figure 1. Leaching of $\mathrm{K}$ from Sandy Loam and Red Clay Loam in the Presence and Absence of Biochar.

Ca leaching was reduced significantly $(P<0.05)$ at $25 \mathrm{t} /$ ha biochar applied red clay loam compared to the control but biochar at higher applications rates had no effect (Figure 2a). Similarly, Mg leaching was reduced by $23 \%$ at $25 \mathrm{t} /$ ha biochar compared to the control (Figure 3). Overall results showed that the higher rates of biochar application had no effect on $\mathrm{Ca}$ and $\mathrm{Mg}$ leaching in red clay loam.

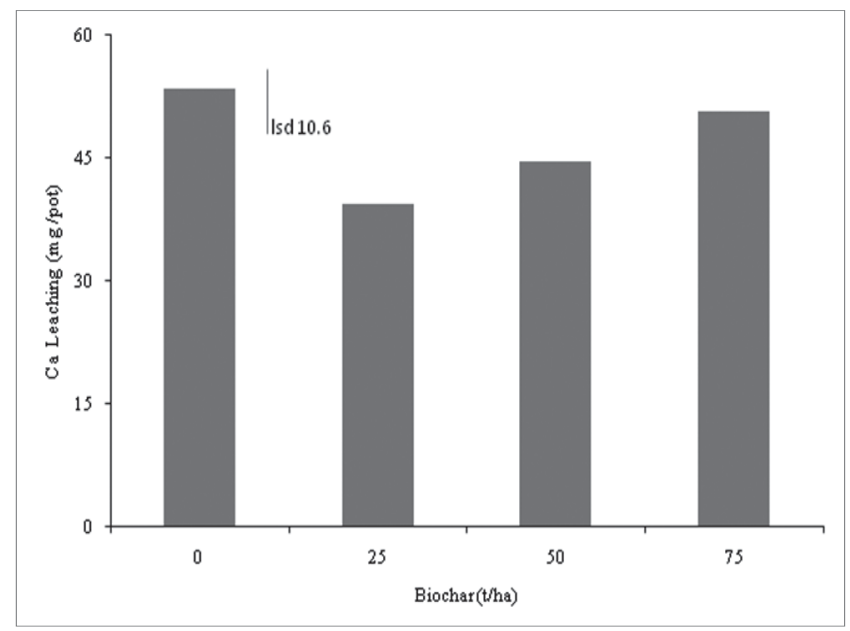

Figure 2a. Leaching of Ca from Biochar Applied and Non Applied Red Clay Loam.

In sandy loam, Ca leaching was significantly $(P<0.05)$ reduced by $23 \%$ at $25 \mathrm{t} / \mathrm{ha}$ biochar compared to the control (Figure 2b). However, the leaching was increased significantly at $75 \mathrm{t} / \mathrm{ha}$. In the case of $\mathrm{Mg}$, biochar did not have any effect at $25 \mathrm{t} /$ ha but it increased at $75 \mathrm{t} /$ ha (Figure 3). Na leaching was significantly $(P<0.05)$ increased with biochar application in both soils and at all applications rates, except at $50 \mathrm{t}$ /ha in red clay loam (Figure 4). 


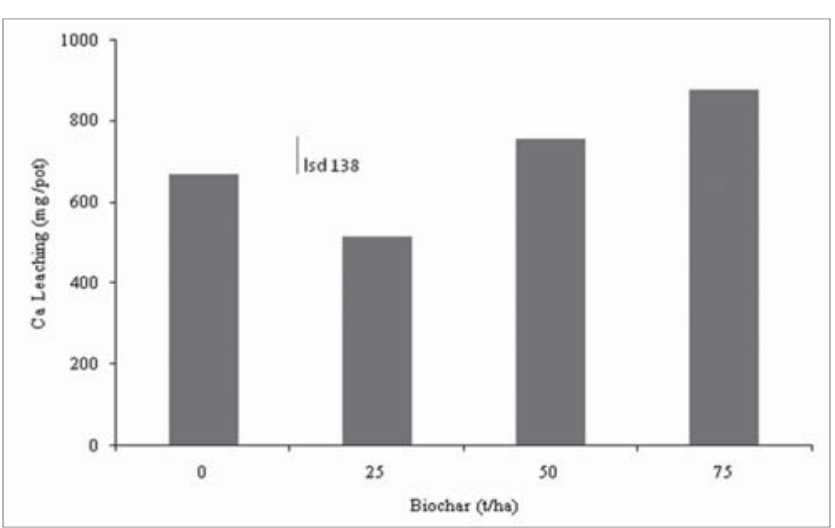

Figure 2b. Leaching of Ca from Biochar Applied and Non Applied Sandy Loam.

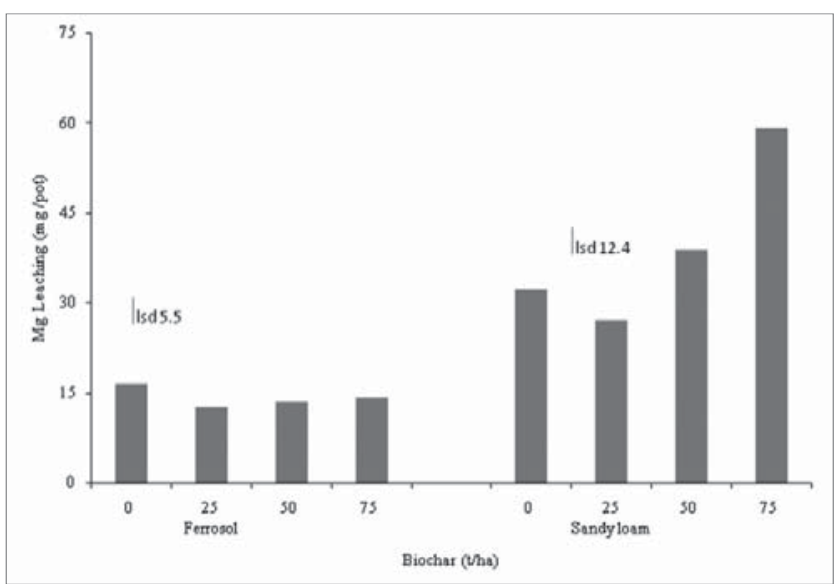

Figure 3. Leaching of Mg from Biochar Applied and Non Applied Red Clay Loam and Sandy Loam.

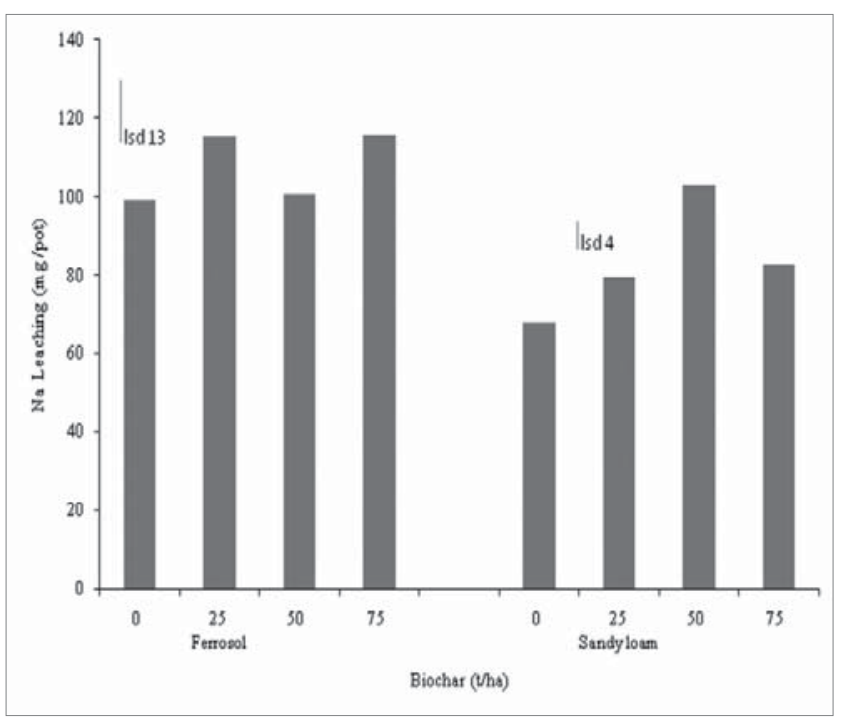

Figure 4. Leaching of $\mathrm{Na}$ from Biochar Applied and Non Applied Red Clay Loam and Sandy Loam.

The volume of leachate produced was significantly $(P<0.05)$ reduced by $12 \%$ and $30 \%$ in sandy loam at 50 $\mathrm{t} / \mathrm{ha}$ and $75 \mathrm{t} / \mathrm{ha}$ respectively. However, there was no differences in red clay loam at $25 \mathrm{t} / \mathrm{ha}$ and $50 \mathrm{t} / \mathrm{ha}$ biochar but significantly $(P<0.05)$ reduced by $20 \%$ at the highest application rate (Figure 5).

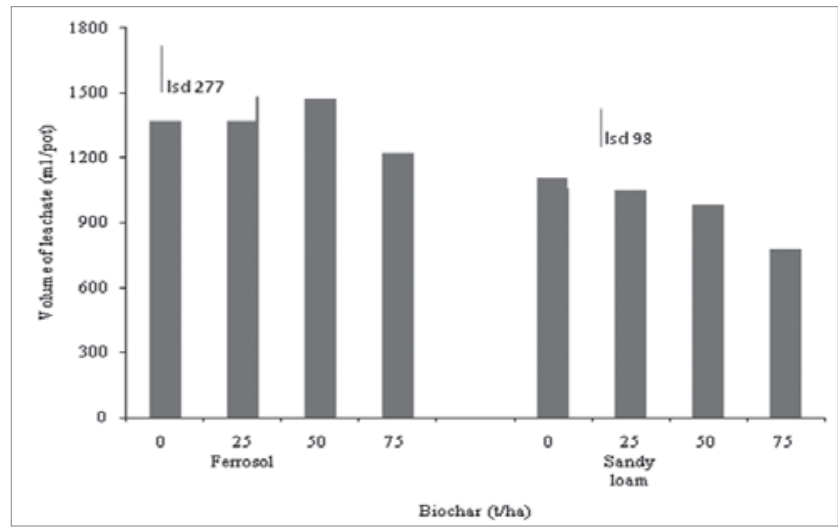

Figure 5. Volume of Leachate Collected from Red Clay Loam and Sandy Loam in the Presence and Absence of Biochar.

\section{Soil Properties}

The water holding capacity of both soils increased with biochar application, but the increment was significant only at $50 \mathrm{t} / \mathrm{ha}$ and $75 \mathrm{t} / \mathrm{ha}$ (Figure 6 ). This trend was negatively correlated (r-0.89) to the volume of the leachate produced.

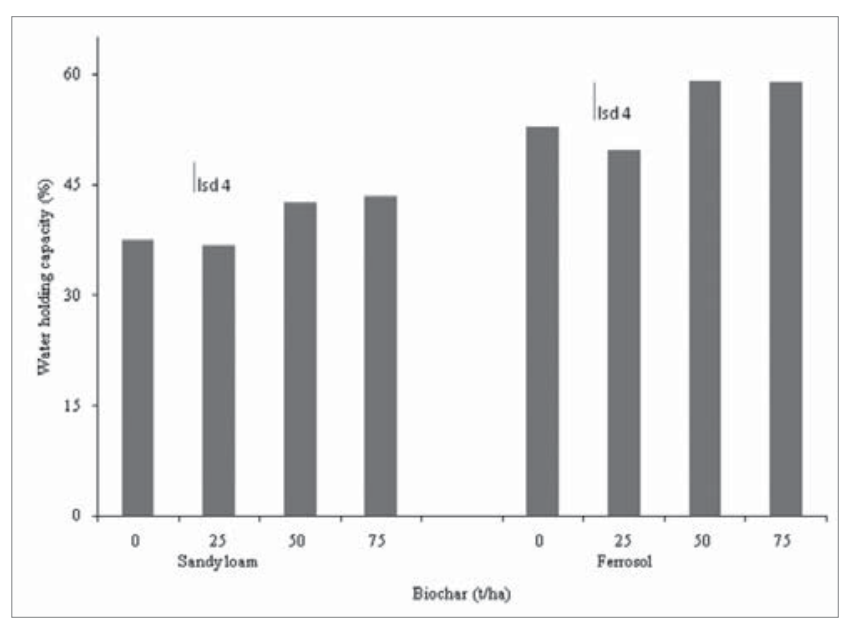

Figure 6. Water Holding Capacity of Red Clay Loam and Sandy Loam in the Presence and Absence of Biochar.

Only the soils that were amended with $25 \mathrm{t} /$ ha biochar were analysed to determine CEC and soil organic carbon. The results showed a slight increase in CEC from 4.97 to $5.19 \mathrm{meq} / 100 \mathrm{~g}$ in sandy loam and 8.19 to $8.63 \mathrm{meq} / 100 \mathrm{~g}$ in red clay loam. The CEC of the biochar was $3.52 \mathrm{meq} / 100$ g. Soil organic carbon increased by $23 \%$ in red clay loam and $19 \%$ in sandy loam at $25 \mathrm{t} / \mathrm{ha}$ biochar compared to the control.

\section{Plant Yield}

Capsicum shoot biomass significantly $(P<0.05)$ increased in biochar applied treatments compared to the controls at $25 \mathrm{t} / \mathrm{ha}$ in sandy loam and red clay loam (Figure 7). In sandy loam, the biomass tended to increase with higher doses of biochar, but these increments were not significant compared to $25 \mathrm{t} / \mathrm{ha}$. However, biochar had no effect in red clay loam at higher rates of application. The $25 \mathrm{t} /$ ha biochar improved shoot biomass by $32 \%$ and $31 \%$ in sandy loam and red clay loam respectively, compared to the control (Figure 7). 


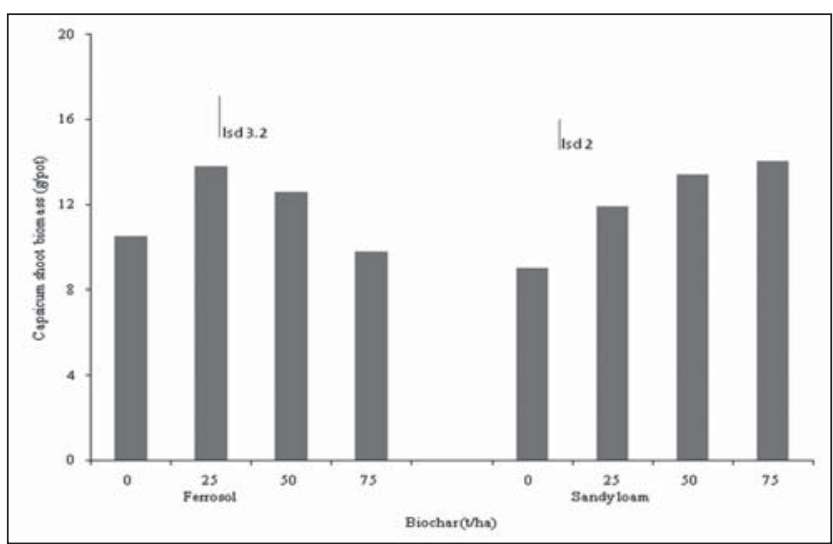

Figure 7. Total above Ground Capsicum Biomass in Red Clay Loam and Sandy Loam in the Presence and Absence of Biochar. The Bars Represent Least Significant Difference $(P<0.05))$.

\section{Discussion}

The current pot experiment has clearly demonstrated that the addition of biochar at $25 \mathrm{t} /$ ha can significantly $(P<O .05)$ improve shoot biomass of capsicum in sandy loam and red clay loam. The improved plant growth at $25 \mathrm{t} / \mathrm{ha}$ may be due to reduced leaching of $\mathrm{Ca}$ and $\mathrm{K}$ in sandy loam and $\mathrm{Ca}$ in red clay loam. Major (2009) also reported that the increased growth of maize was associated with reduced nutrient leaching in Savanna acidic Oxisol amended with $20 \mathrm{t} / \mathrm{ha}$ biochar. In her research, maize yield was improved by $140 \%$, and $\mathrm{K}$ and Ca leaching were reduced by $36 \%$ and $23 \%$ respectively from biochar amended poor acidic soil, compared to the control.

Higher biochar application rates (50 t/ha and 75 t/ ha) enhanced shoot biomass of capsicum compared to $25 \mathrm{t} /$ ha in sandy loam, however the increments were not significant $(P>0.005)$. It is possible that $\mathrm{N}$ available in the soil at higher rates of biochar was reduced as green waste biochar contained high total carbon (62.9\%) and low nitrogen (Table 1 ), and available $\mathrm{N}$ could also been used up by microbial activity and hence not allowing plants to enhance growth. This finding contrasts to a previous study by Chan, Van Zwieter et al (2007), who reported that radish yield was increased with increasing rates of green waste biochar application in the presence of nitrogen fertiliser in hard setting Alfisol. The yield increment was 266\% at $100 \mathrm{t} /$ ha green waste biochar applied soil compared to the control. The differences between two experiments are application of fertilizer rates. In the study of Chan, Van Zwieter et al (2007), the $\mathrm{N}$ fertiliser was applied at 100 $\mathrm{kg} /$ ha with $100 \mathrm{t} /$ ha green waste biochar, where as in the current study, only $25 \mathrm{~kg} / \mathrm{ha} \mathrm{N}$ was applied with $50 \mathrm{t} / \mathrm{ha}$ and $75 \mathrm{t} /$ ha green waste biochar.

Biochar amendment did not improve water holding capacity of both soils at $25 \mathrm{t} / \mathrm{ha}$, possibly due to adequate time required for changes in physical properties of the soil. However, higher doses of biochar application did improve water holding capacity of both soils as biochar has higher WHC $(2.75 \mathrm{ml} / \mathrm{g})$ than soil. This suggests that the effects of biochar on soil physical properties might require longer term observations.

Higher doses (50 and $75 \mathrm{t} / \mathrm{ha}$ ) of biochar produced varying effects in the two soils in terms of plant growth and cation leaching. For example, for plant growth, they showed positive (significant) effect in sandy loam and negative or neutral (non-significant) effect in red clay loam. Likewise, $\mathrm{Ca}$ and $\mathrm{Mg}$ leaching showed contrasting effects between two soils, and increased leaching of $\mathrm{Na}$ in both soils. These varying responses of the two soils to biochar application may be explained by differences in their ability to support plant growth, retain nutrients and water.

Overall, biochar application to sandy loam and red clay loam at $25 \mathrm{t} /$ ha improved capsicum shoot biomass by $32 \%$ and $31 \%$ respectively over control. This also reduced leaching of $\mathrm{K}, \mathrm{Ca}$ and $\mathrm{Mg}$ at 40\%, 23\% and 23\% respectively. However, the responses of the two soils to higher doses of biochar application are not consistent and require further investigation.

In this study, biochar did not have an effect on soil CEC in this study. This may be due to shorter length of exposure (only three months) which might not be adequate for the oxidation on biochar surfaces in the soil and result in increased soil CEC as it increases as the biochar ages in soil (Cheng, Lehmann and Engelhard 2008).

\section{Conclusions}

The application of $25 \mathrm{t} / \mathrm{ha}$ green waste biochar significantly reduced $\mathrm{K}$ and $\mathrm{Ca}$ leaching in sandy loam, and $\mathrm{Ca}$ leaching in red clay loam. Biochar application (25 t/ha) also increased capsicum shoot biomass in both sandy loam and red clay loam. This experiment thus demonstrates that the addition of 25 t/ha green waste biochar can improve plant growth and it can also reduce cation leaching in both sandy loam and red clay loam soils. However, higher doses (50, $75 \mathrm{t} / \mathrm{ha}$ ) of biochar produced varying effects in the two soils in terms of plant growth and cation leaching. Further research is therefore needed to explain the different responses shown in the two soils with higher rates of biochar. Furthermore, the trends recorded in the pot experiments must be tested in a field experiment to place any practical implications on the effects of biochar on plant growth and nutrient leaching.

\section{Acknowledgements}

The authors thank Pacific Pyrolysis Pty. Ltd. for providing green waste biochar, capsicum grower Steve Franchetto for assistance with soil collection and providing information about soil and crop history, and CQ University for financial support.

Kalpana Pudasaini is a PhD candidate at Center for Plant and Water Science, CQ University, Australia. She is examining the role of biochar in changing soil properties and plant yield. She completed her Masters Degree in Environmental Science at Tribhuvan University in 2004 with distinction. She has more than five years of professional experience in environment, natural resource management and agriculture sectors specifically in Nepal, England and Australia.

Corresponding address: k.pudasaini@cqu.edu.au

Nanjappa Ashwath, PhD, Associate Professor, has been working with Center for Plant and Water Science, CQ University, Australia since 1995. He has been involved in wide range of research areas such as biochar, green waste, biofuel, phyto-capping, rehabilitation and 
restoration of native vegetation. He was a PhD Scholar between 1983 and 1986 at Australian National University (ANU), and after completing his PhD he worked as a Research Scientist for five years for the Commonwealth Scientific and Industrial Research Organisation (CSIRO) Forestry and five years for Environment Australia in Northern Territory.

Kerry Walsh, PhD, Professor, is plant physiology professor and Deputy Director at Center for Plant and Water Science, and Associate Dean of Research and Innovation at CQ University, Australia. He completed his Masters in 1985 and PhD in 1988, both from Queens University, Canada.

Thakur Bhattarai, is a PhD candidate at Center for Plant and Water Science, CQ University, Australia. He completed a MSc in natural resource management at Cranfield University in the UK in 2005. He has received several international and national awards and scholarships for his academic and professional qualifications and training. Prior to PhD studies he worked with government and non-governmental organisations in Nepal for more than 10 years and attended several sort-term courses, training, workshops and conference nationally and internationally.

\section{References}

Brady, N. and R. Weil, 2008, The Nature and Properties of Soils (14th ed.), Upper Saddle River, NJ: Prentice Hall.

Beaton, J.D., H.B. Peterson and N. Baur, 1960, 'Some aspects of phosphate adsorption to charcoal', Proceedings of Soil Science Society of America 24:340346.

Cahn, M., D. Bouldin, M. Cravo and W. Bowen, 1993, 'Cation and nitrate leaching in an Oxisol of the Brazilian Amazon', Agronomy Journal 85:334-334.

Chan, K.Y., L. Van Zwieten, I. Meszaros, A. Downie and S. Joseph, 2007, 'Agronomic values of greenwaste biochar as a soil amendment', Australian Journal of Soil Research 45(8):629-634.

Chapman, H.D., 1965, 'Cation-exchange capacity', in C.A. Black (ed.), Methods of Soil Analysis: Chemical and Microbiological Properties, Agronomy Journal 9:891901.

Cheng, C., J. Lehmann and M. Engelhard, 2008, 'Natural oxidation of black carbon in soils: Changes in molecular form and surface charge along a climosequence',
Geochimica et Cosmochimica Acta 72(6):1598-1610.

Juo, A.S.R. and A. Manu, 1996, 'Chemical dynamics in slash-and-burn agriculture', Agriculture, Ecosystems and Environment 58:49-60.

Lehmann, J., J. da Silva Jr., M. Rondon, M.S. Cravo, J. Greenwood, T. Nehls, C. Steiner and B. Glaser, 2002, 'Slash-and-char: A feasible alternative for soil fertility management in the central Amazon?', in Proceedings of the 17th World Congress of Soil Science, Bangkok, Thailand.

Lehmann, J., J. Lilienfein, K. Rebel, S. do Carmo Lima and W. Wilcke, 2004, 'Subsoil retention of organic and inorganic nitrogen in a Brazilian savanna Oxisol', Soil Use and Management 20(2):163-172.

Lehmann, J., J.P. da Silva, C. Steiner, T. Nehls, W. Zech and B. Glaser, 2003, 'Nutrient availability and leaching in an archaeological Anthrosol and a Ferralsol of the Central Amazon basin: Fertilizer, manure and charcoal amendments', Plant and Soil 249(2):343-357.

Liang, B., J. Lehmann, D. Solomon, J. Kinyangi, J. Grossman, B. O'Neill, J. Skjemstad, J. Thies, F. Luizao and J. Petersen, 2006, 'Black carbon increases cation exchange capacity in soils', Soil Science Society of America Journal 70(5):1719.

Major, J., 2009, Biochar Application to a Colombian Savana Oxisol: Fate and Effect on Soil Fertility, Crop Productivity, Nutrient Leaching and Soil Hydrology, PhD Dissertation, Faculty of the Graduate School, Cornell University, Ithaca, New York.

Mizuta, K., T. Matsumoto, Y. Hatate, K. Nishihara and T. Nakanishi, 2004, 'Removal of nitrate nitrogen from drinking water using bamboo powder charcoal', Bioresource Technology 95:255-257.

Omoti, U., D. Ataga, and A. Isenmila, 1983, 'Leaching losses of nutrients in oil palm plantations determined by tension lysimeters', Plant and Soil 73(3):365-376.

Radovic, L.R., C. Moreno-Castilla and J. Rivera-Utrilla, 2001, 'Carbon materials as adsorbents in aqueous solutions', pp. 227-405 in L.R. Radovic (ed.), Chemistry and Physics of Carbon, New York: Marcel Dekker.

Walkley, A., 1947, 'A critical examination of a rapid method for determining organic carbon in soils: Effect of variations in digestion conditions and of inorganic soil constituents', Soil Science 63:251-64.

Woolf, D., 2008, Biochar as a Soil Amendment: A Review of the Environmental Implications (unpublished study), Swansea University, School of the Environment and Society. URL: http://orgprints.org/13268/. 